\title{
On the origin and evolution of a new anchialine stygobitic Microceratina species (Crustacea, Ostracoda) from Christmas Island (Indian Ocean)
}

\author{
TADEUSZ NAMIOTKO ${ }^{1}$, KAREL WOUTERS $^{2}$, DAN L. DANIELOPOL ${ }^{3} \&$ WILLIAM F. HUMPHREYS \\ ${ }^{1}$ University of Gdan̄sk, Department of Genetics \& Cytology, Kladki 24, 80-822 Gdan̄sk, Poland (e-mail: namiotko@biotech.univ.gda.pl). \\ ${ }^{2}$ Royal Belgian Institute of Natural Sciences, Department of Invertebrates, Vautierstraat 29, B-1000 Brussels and Department of Biology, \\ K.U. Leuven, Leuven, Belgium (e-mail: karel.wouters@naturalsciences.be). \\ ${ }^{3}$ Austrian Academy of Sciences, Limnological Institute, Mondseestraße 9, A-5310 Mondsee, Austria (e-mail: dan.danielopol@oeaw.ac.at). \\ ${ }^{4}$ Western Australian Museum, Francis Street, Perth, Western Australia-6000, Australia (e-mail: bill.humphreys@museum.wa.gov.au).
}

\begin{abstract}
Marine species of the ostracod genus Microceratina Swanson (Cytheruridae, Eucytherurinae) were until now known only from their hard parts, the valves and carapaces, as no living animals have been described. Here we report the first living population, from a tropical anchialine cave. The description of the limbs and hard parts of this new taxon, M. martensi sp. nov., enhances our understanding of the origin and evolution of the cave-dwelling Microceratina - the new species and M. pseudoamfibola (Barbeito-Gonzalez) from an anchialine cave in Southern Italy - and clarifies their affinities with other Eucytherurinae species. Microceratina is known from both Recent and fossil species (Quaternary, Tertiary and Late Cretaceous) from shelf and deep-sea habitats and/or sedimentary facies, located in the Pacific Ocean (along the Australian and New Zealand coasts), the Mediterranean (Greece and Italy), the North Atlantic (British Isles) and the Baltic Sea (Rügen Island). This suggests that the Microceratina group spread through the expanding Tethys Ocean. The morphological traits of the two cave-dwelling species reflect their ecological conditions. Cave-dwelling Microceratina species appear to have originated from epigean shallow water species predisposed to colonize subterranean habitats. J. Micropalaeontol. 23(1): 49-59, May 2004.
\end{abstract}

\section{INTRODUCTION}

Ostracods of the family Cytheruridae G.W. Müller are exclusively marine and brackish water-dwelling species which inhabit a wide range of coastal and deep-sea habitats (Kempf, 1986; Hartmann, 1989). Representatives of the genus Microceratina Swanson, 1980 are known from the Southern Hemisphere at sites close to the Australian and New Zealand coasts (Swanson, 1980; Whatley \& Downing, 1983; Yassini \& Jones, 1995) and from the Northern Hemisphere, in the Mediterranean (Greece and Italy; Mazzini \& Gliozzi, 2000). Microceratina is a cytherurid genus recorded from the Late Cretaceous (Herrig, 1991) to Recent. However, until now, the nine species attributed to this genus have been described from empty carapaces and/or valves, the material coming from open marine environments, with the exception of Microceratina pseudoamfibola (Barbeito-Gonzalez, 1971), which was described from an anchialine cave in southern Italy (Mazzini \& Gliozzi, 2000).

The discovery of a living stygobitic population of a new Microceratina species within the karstic system of tropical Christmas Island in the Indian Ocean is important as it represents the first Microceratina species for which the appendages can be described. Furthermore, it presents the opportunity to reconstruct the origin and evolution of this phylogenetic lineage which has produced a clearly stygobitic species. Pursuit of this goal is worthwhile because there are few well-documented cases where both living and fossil records of ostracods have been used to reconstruct the pattern of colonization and the manner of their adaptation to the subterranean environment. One of the most complete reconstructions of the evolutionary history resulting in stygobitic species is of the Danielopolina group (Danielopol et al., 2000).

\section{GEOLOGICAL AND HYDROLOGICAL SETTING}

Christmas Island lies in the Indian Ocean, about $350 \mathrm{~km}$ southwest of Java and $1200 \mathrm{~km}$ west of the Australian continent. Grimes (2001) reviewed the sparse knowledge of the geomorphology, geology and genesis of the cave systems on the island and Humphreys \& Eberhard $(1998,2001)$ have discussed the natural history of the island as it pertains to the subterranean fauna. Christmas Island, which is the tip of an isolated seamount rising $4.5 \mathrm{~km}$ from the ocean floor in the Wharton Basin of the Indian Plate, is the only member exposed above sea-level of a series of volcanoes that formed from the midCretaceous, starting about $80 \mathrm{Ma}$. As it is drifting northwards $\left(70-80 \mathrm{~mm} \mathrm{a}^{-1}\right)$ it will descend into the Java Trench in about four million years (Grimes, 2001). The island, which reaches an altitude of $361 \mathrm{~m}$, is small $\left(135 \mathrm{~km}^{2}\right)$ and is capped by a sequence of Tertiary limestones up to $250 \mathrm{~m}$ thick (Pettifer \& Polak, 1979) that overlie the basaltic rocks that form the core of the island. Because the island is rising $c .140 \mathrm{~mm} \mathrm{ka}^{-1}$ (Woodroffe, 1988) it is flanked by a series of emergent limestone terraces. Volcanism was reactivated in the Eocene (35-40 Ma) from which date there is a series of poorly exposed carbonates, the main exposures being of Late Oligocene to Middle Miocene age. The exposed landmass would never have been substantially larger than at present due to the steep submarine slopes on the island, but at times the island could have been both much smaller (even submerged) and fragmented, if, as suggested by Barrie (1967), an atoll was present. The main limestones contain fossils laid down in shallow water (Adams \& Belford, 1974) in the Late Oligocene (26 Ma). Deposition of the main limestones ceased at the end of the Middle Miocene (c. $14 \mathrm{Ma}$ ) as a result of the global fall in sea-level and exposed limestones were then subjected to several 


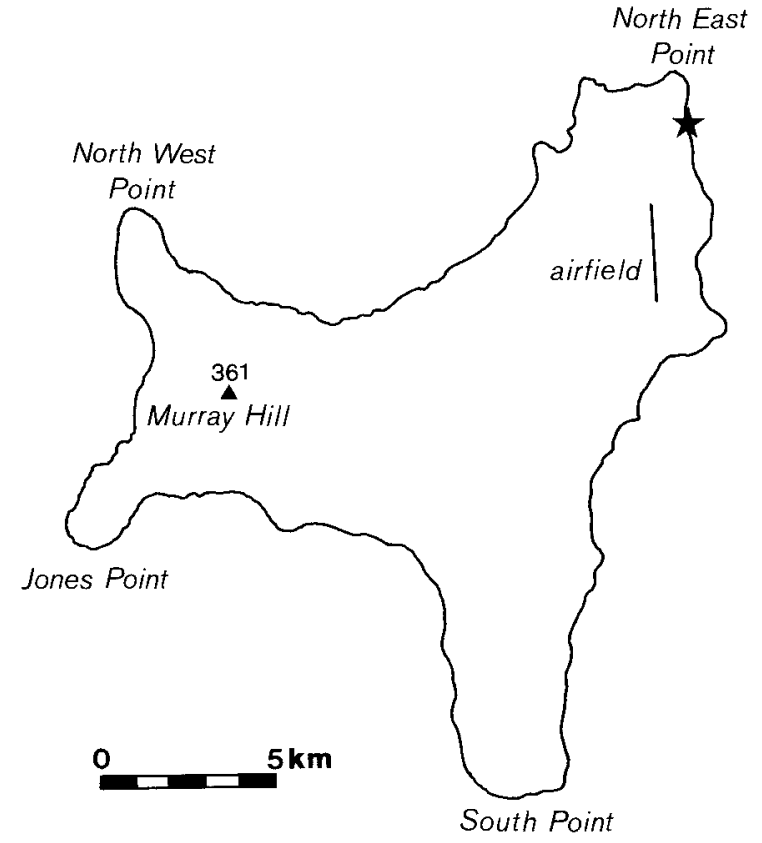

Fig. 1. Map of Christmas Island with the location of the sampling sites (black star).

million years of karst development. The lack of extensive Pliocene or Pleistocene limestone deposition suggests that the island has not been extensively submerged since the Miocene (Grimes, 2001).

The rainfall (annual mean $2109 \mathrm{~mm}$ : Falkland, 1986) is highly variable owing to the impact on the island of the El Niño/ Southern Oscillation (ENSO) but supports rainforest covering the island. Typical of karst drainage, rainfall infiltrates the limestone and then mostly drains down the slope of the underlying basalt until reaching the sea in caves and through coastal and offshore springs (Pettifer \& Polak, 1979). A low lens of fresh groundwater occurs in some areas (Barrett, 1985).

Waters on the plateau are fresh (Total Dissolved Solids (TDS) 195-280 $\mathrm{mg} \mathrm{dm}^{-3}$ : Polak, 1976) but mix with seawater near the coast and so will accelerate karst formation through the effects of mixing corrosion (Ford \& Williams, 1989) to develop salt-freshwater interface caves (e.g. from the Bahamas see Vogel et al., 1990; Mylroie et al., 1991). Because sea-level stands during the Pleistocene were predominantly much lower (Chappell \& Thom, 1977) these caves are likely to extend at least $80 \mathrm{~m}$ below the present sea-level, notwithstanding an uplift of the island of $14-20 \mathrm{~m}$ in the last $124 \mathrm{ka}$ (Woodroffe, 1988). Speleothems drowned by at least $6 \mathrm{~m}$ provide evidence of lower sea-level (Humphreys \& Eberhard, 1998) and submarine springs have been reported at a depth of $200 \mathrm{~m}$ in Flying Fish Cove (Pettifer \& Polak, 1979).

\section{CHARACTERISTICS OF THE SAMPLING SITE}

The new species was found amongst roots in an anchialine pool in a small, unnamed cave CI-54, situated in the North East Point of Christmas Island (Fig. 1). The cave is probably connected to two adjacent anchialine caves, Runaway Cave (CI-2) and The 19th Hole (CI-19), and these three caves are treated here as a single anchialine system.

The caves open on the lowest terrace, close to the coast. Waters within the caves are affected by marine tides, have different surface salinities and show the salinity stratification typical of anchialine waters (Table 1) (Humphreys \& Eberhard, 1998). Cave CI-54 lies between Runaway Cave and the coast, therefore, the salinity is likely to be greater than the brackish water (salinity c. 9-18 ppt) in Runaway Cave (Table 1), but not substantially greater as the ostracod was collected amongst submerged roots of rainforest plants. After heavy rain the uppermost water layer will probably be dominated by underground freshwater drainage from the plateau (TDS of 195-280 $\mathrm{mg} \mathrm{dm}^{-3}$; Polak, 1976). The cave waters are well oxygenated but have not been sampled at any depth either for their biota or for physico-chemical parameters. It is not known, therefore, whether the deeper water becomes suboxic as reported for many other anchialine systems (Sket, 1996; Humphreys, 1999; Iliffe, 2000).

Although cave CI-54 was not sampled thoroughly for fauna, the following aquatic taxa accompanied the new ostracod species: Syllidae indet. (Polychaeta); Nerilla sp. (Archiannelida: Nerillidae); Nitocrella/Nitokra complex (Harpacticoida: Ameiridae); Bryocyclops muscicola (Menzel) (Cyclopoida: Cyclopinidae); a new copepod genus (Calanoida: Arietellidae); Leucothoe sp. (Amphipoda: Leucothoidae); Alpheidae indet. (Decapoda); Parahippolyte uveae Borradaile (Decapoda: Hippolytidae); Antecaridina lauensis (Edmondson) (Decapoda: Atyidae; found also in CI-2 and CI-19); Macrobranchium lar (Fabricius) (Decapoda: Palaemonidae); Gobioidae indet. (Pisces: Perciformes). In CI-2 Procaris sp. nov. (Decapoda: Procarididae) and Eleotridae indet. (Pisces: Perciformes) were encountered.

\section{MATERIAL AND METHODS}

Groundwaters of caves CI-54, Runaway Cave (CI-2) and 19th Hole (CI-19) were sampled directly but other groundwaters on

\begin{tabular}{|c|c|c|c|c|c|c|}
\hline \multirow[t]{2}{*}{ CAVE } & & \multicolumn{2}{|c|}{ Dissolved oxygen } & \multirow{2}{*}{$\begin{array}{l}\text { Conductivity } \\
\mathrm{mS} \mathrm{cm}^{-1}\end{array}$} & \multirow{2}{*}{$\begin{array}{c}\text { Temperature }^{\mathrm{a}} \\
{ }^{\circ} \mathrm{C}\end{array}$} & \multirow[t]{2}{*}{$\mathrm{pH}$} \\
\hline & & $\mathrm{mg} \mathrm{dm}^{-3}$ & $\%$ & & & \\
\hline Runaway Cave (CI-2) & surface & 7.06 & 97.7 & 5.5 & 26.9 & 7.99 \\
\hline \multirow[t]{2}{*}{ The 19th Hole (CI-19) } & surface & 6.60 & 94.0 & 31.2 & 27.0 & 7.60 \\
\hline & $2 \mathrm{~m} \mathrm{depth}$ & 5.05 & 73.0 & 34.4 & 27.4 & 7.35 \\
\hline
\end{tabular}

From Humphreys \& Eberhard (1998)

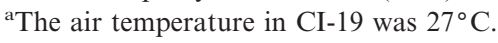

Table 1. Some physical and chemical parameters of groundwaters from anchialine caves adjacent to the sampling site Cave CI-54, recorded on 5-6 April 1998. 
the island were sampled through springs and boreholes. Samples were taken variously by hand-net following visual sighting of fauna, by plankton nets of appropriate dimensions hauled through the water column, with or without pre-baiting, and/or by the use of baited traps left in place overnight. Ostracods were collected in cave CI-54 by S. M. Eberhard on 13 April 1998. Physico-chemical parameters of groundwaters were measured in situ using electronic instruments (Watts \& Humphreys, 2000): pH using a WTW pH 320 meter with a SenTix 97T pHcombined electrode with integrated temperature sensor and redox probe and dissolved oxygen using a WTW Oxi 320 meter and a CellOx 325 oxygen sensor (Wissenschaftlich-Technisch Werkstatten $\mathrm{GmbH}$, Weilheim, Germany). Conductivity was measured with a TPS Model LC 84 conductivity meter (TPI Electronics, Springwood, Queensland, Australia). All were calibrated as specified using the recommended standards.

Dissected specimens were mounted in glycerine on slides, with valves stored dry in micropalaeontological cells, whereas entire specimens were preserved in $97 \%$ ethanol in a glass tube. Valve dimensions were measured to the nearest $0.01 \mathrm{~mm}$ under the stereomicroscope at $\times 500$. Valves and appendages were examined and drawn using a microscope fitted with a drawing tube at magnifications of $\times 500, \times 800$ or $\times 2000$ (oil immersion). Selected valves were prepared for the SEM and studied at the SEM laboratory of the Royal Belgian Institute of Natural Sciences in Brussels.

\section{SYSTEMATIC DESCRIPTION}

Order Podocopida G.W. Müller, 1894

Suborder Podocopina Sars, 1866

Superfamily Cytheroidea Baird, 1850

Family Cytheruridae G.W. Müller, 1894

Subfamily Eucytherurinae Puri, 1974

(emend. Maddocks \& Steineck, 1987)

Genus Microceratina Swanson, 1980

Type species. Microceratina quadrata Swanson, 1980 (by original designation).

Microceratina martensi sp. nov.

(Pl. 1, figs 1-7, Figs 2-4)

Derivation of name. Named after our colleague and friend Koen Martens (Royal Belgian Institute of Natural Sciences, Brussels), in recognition of his important contributions to the study of ostracods.

Diagnosis. A small species of Microceratina with well-developed valve reticulation and distinct ventro-lateral ridges along alar process; dorsal and ventral margins weakly tapering towards the posterior; pore clusters of the loophole type, with three subcircular to oval holes. Body unpigmented, no visible ocular structures.

Holotype. A female with valves stored dry and dissected limbs preserved in a sealed glycerine preparation (C 28908), deposited in the collections of the Western Australian Museum, Perth.

Paratypes. Four females with valves stored dry and dissected limbs preserved in a sealed glycerine preparation (C 28909-C
28912), one female carapace (C 28913), one female carapace with disarticulated valves (C 28914), and 15 adult females and 9 juveniles preserved in ethanol (C 28915), deposited in the collections of the Western Australian Museum, Perth.

Type locality. Cave CI-54 (unnamed) opening on the lowest terrace, close to the coast, $c$. $1.5 \mathrm{~km}$ south from the North East Point of Christmas Island, Indian Ocean (geographical co-ordinates: $c$. $10^{\circ} 25^{\prime} 20^{\prime \prime} \mathrm{S}, 105^{\circ} 42^{\prime} 02^{\prime \prime} \mathrm{E}$; altitude: entrance $c$. $10 \mathrm{~m}$ above sea-level; water at sea-level). For details, see the previous section.

Horizon. Recent.

\section{Description of female}

Valves. (Fig. 2a-b; Pl. 1, figs 1-7) Very small, somewhat translucent and elongate. Dorsal margin straight, ventral margin weakly sinuous; dorsal and ventral margins weakly tapering towards the posterior. Anterior margin evenly rounded, with a large flange, posterior margin evenly rounded. Lateral surface inflated, forming a mid-ventral and postero-ventral alar process. Carapace in dorsal view broad, with nearly parallel lateral margins; anterior and posterior extremities pointed. Ornamentation consisting of a distinct reticulate pattern of polygonal meshes, each mesh being subdivided into a number of smaller meshes surrounded by fine polygonal muri; two to three longitudinal ventral striae near the expansion of the alar process. Pore clusters of the loophole type with three subcircular to oval holes. Anterior and posterior inner lamellae wide. Anterior vestibulum narrow, with nine broad marginal pore canals, some of them false, with a central bulbous widening. Posterior vestibulum shallow and elongate, with five to six broad marginal pore canals. Hinge weakly developed, merodont, with very weakly crenulated (difficult to see), small and elongate terminal teeth and in the right valve a shallow central groove. Muscle scar pattern consisting of an oblique row of four elongate adductor scars and a large $\mathrm{V}$ - to U-shaped frontal scar. The imprints of the muscle scars are visible on the external side of the valves as small protuberances of nearly the same shape as the scars.

Size of carapace. Holotype length $(L) 0.31 \mathrm{~mm}$, height $(H)$ $0.15 \mathrm{~mm}$; paratypes $(n=6) L 0.31-0.33 \mathrm{~mm}, H 0.13-0.15 \mathrm{~mm}$.

Antennule. (Fig. 3a) Consisting of five functional, generally slender podomeres (2-segmented base and 3-segmented ramus), although the equivalents of seven podomeres can be recognized. First podomere dorso-distally with a row of thin setulae. Second and third podomeres not differentiated, without any visible suture. The ventro-median point of insertion of the long seta (reaching beyond the distal end of fifth podomere) marks the former boundary between these two podomeres. Both of these podomeres, forming one compound segment, set dorsally with brushes consisting of long setulae. Fourth podomere (the first podomere of the ramus) with one dorso-distal seta. Fifth and sixth podomeres incompletely differentiated, joined by an indistinct, inflexible suture. Fifth podomere bearing three setae: two unequal dorsal setae, and one ventral seta, while sixth podomere set with four setae: two very long and one short dorsal setae, and 


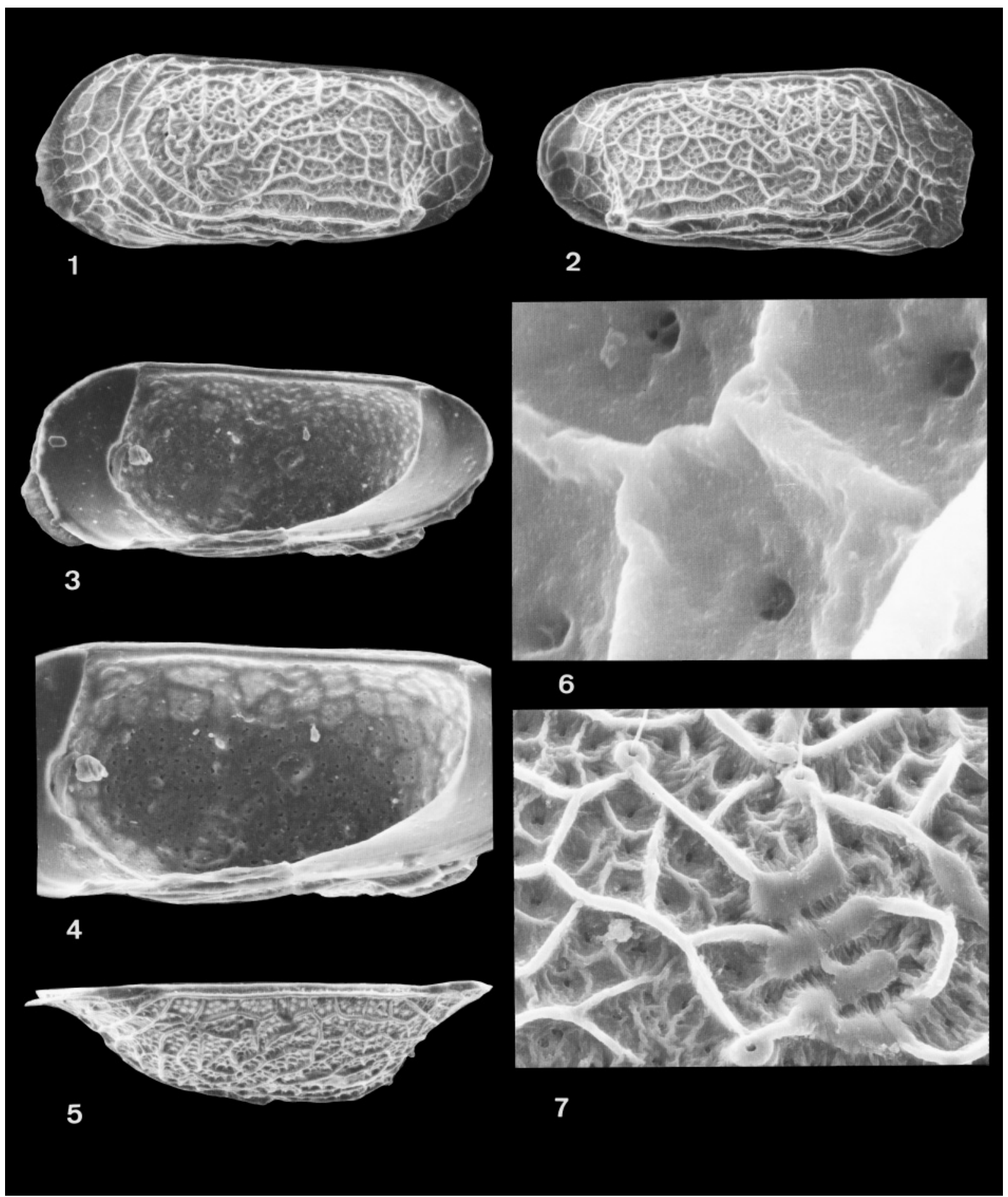

Explanation of Plate 1. Microceratina martensi sp. nov., Christmas Island. All figured specimens are females. fig. 1. Left valve, external view, paratype (C 28910), × 250. fig. 2. Right valve, external view, paratype $($ C 28909), $\times 250$. fig. 3. Right valve, internal view, holotype (C 28908$)$, $\times 250$. fig. 4. Right valve, internal view, holotype, $\times 310$. fig. 5. Left valve, dorsal view, holotype, $\times 250$. fig. 6 . Right valve, detail of ornamentation and pores, paratype $($ C 28909), $\times 7600$. fig. 7. Right valve, detail of ornamentation, paratype $($ C 28909), $\times 900$.

one additional seta on the ventro-distal corner. Seventh podomere absent. The terminal (eighth) podomere distally with three setae and one aesthetasc. The latter, as long as the ramus, is fused at the base with one adjoining seta and the point of their insertion is located ventrally compared to both remaining setae.
Antenna. (Fig. 3b) Four podomeres and a large exopodite (spinneret seta) extending almost to the tips of the terminal claws. First endopodal podomere sub-quadrangular, with two unequal ventro-distal setae and a brush of fine long setulae inserted on the external surface. Second endopodal podomere 


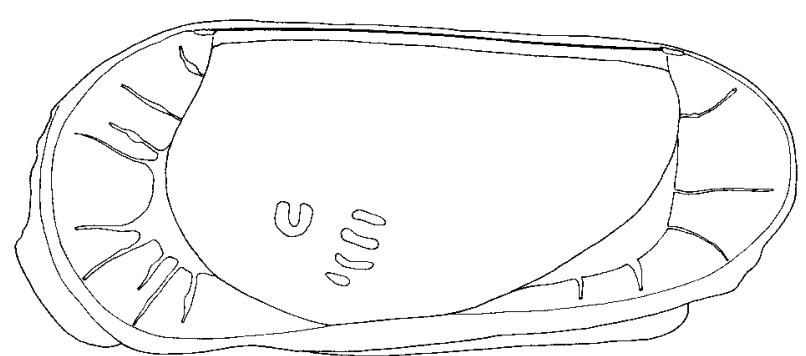

a

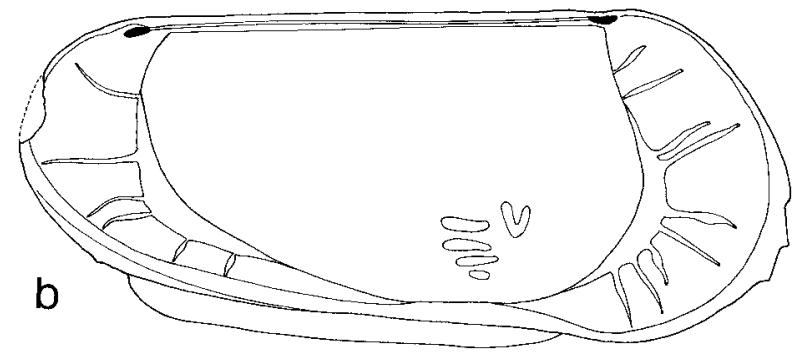

Fig. 2. Microceratina martensi sp. nov., Christmas Island, female specimens: (a) right valve, internal view, holotype (C 28908); (b) left valve, internal view, paratype (C 28910). Scale: $100 \mu \mathrm{m}$.

long and narrow, bearing one seta inserted at two-thirds of the length of the dorsal margin, two sub-equal ventro-median setae as well as one ventro-distal seta. Terminal podomere minute, set with two strong claws associated with externally situated thick seta (aesthetasc).

Mandible. (Fig. 3c) Consisting of coxa and indistinctly 4-segmented palp. Coxa long and stout with one relatively long seta. The masticatory edge of coxa well developed, armed with five or six strong teeth, alternating with spines and followed by at least one hirsute seta. First palp podomere with two unequal, internally directed setae and a vibratory plate (exopodite) bearing only one very long seta. Second palp podomere dorsally with one long seta, one peculiarly bent ventro-distal plumose seta, and two distal setae orientated internally. Third palp podomere in the dorsal two-thirds with five externally directed setae (three long setae reaching tips of the claws on the terminal podomere and two shorter setae), medio-distally with one internally projected seta, and ventro-distally with one long and one short setae (short seta not seen on the left mandible). Terminal palp podomere (about a half of the penultimate podomere) with three sub-equal claw-like setae.

Maxillula. (Fig. 3d) Elongated respiratory plate, three endites and 2-segmented palp. The former carrying at least 16 normal plumous rays on its posterior rim and two aberrant setae pointed downward towards the mouth. First palp podomere bearing at least three long dorso-distal setae. Second palp podomere with 2-3 ventro-median setae and distally with one claw and at least one seta. Endites with unknown exact number of distal setae. These setae being closely packed together and lying on top of one another.
First walking leg. (Fig. 4a) Slender and 4-segmented. First podomere with one long dorso-median seta, one shorter dorsodistal knee-seta and two long ventral setae inserted in the first half of the podomere. The edge of the joint between first and the second podomere with a row of setulae. Second podomere elongated, bearing one antero-distal seta which extends about to the two third of the length of the next (third) podomere. Terminal podomere with a long, slender and regularly curved claw; this claw slightly longer than two last podomeres combined.

Second walking leg. (Fig. 4b) Has the same chaetotaxial armament as in the preceding limb, although with longer podomeres and a claw.

Third walking leg. (Fig. 4c) 4-segmented, with much larger first and second podomeres than those of the second walking leg. First podomere with only one ventral seta and one knee-seta. Second podomere very elongated and slender with one distal seta. Absolute lengths of the penultimate and the terminal podomeres as well as of a claw comparable with those of the second leg.

Caudal rami (furca) and posterior end of the body. (Fig. 4d) Caudal ramus with three setae. Genital operculum ovate. Abdominal extremity conical with obtuse end and with a brush of caudal setulae.

Tegumentary pigments. Not visible.

Ocular structures. Undeveloped.

\section{Males unknown}

Remarks. Nine species of Microceratina were recognized before this study solely on the morphology of the valves. Five of these species, M. pseudamfibola (Barbeito-Gonzalez, 1971), M. poligonia (Colalongo \& Pasini, 1980), M. quadratamicroreticulata Yassini \& Jones, 1995, M. aequabilis Herrig, 1991 and Microceratina sp. 2 Whatley \& Downing, 1983, have only faint reticulation and, therefore, can be easily distinguished from the present species. Furthermore, M. pseudoamfibola is a larger species ( $L 0.40 \mathrm{~mm}$ ) with parallel dorsal and ventral margins; $M$. poligonia is also a larger species $(L 0.51 \mathrm{~mm})$, which, apart from the reticulation, resembles $M$. martensi sp. nov.; M. quadratamicroreticulata is a smaller species $(L 0.28 \mathrm{~mm})$ with nearly parallel dorsal and ventral margins; Microceratina sp. 2 is somewhat larger $(L 0.39 \mathrm{~mm})$ and has a wide ventro-lateral alar process; and $M$. aequabilis is also larger $(L 0.44 \mathrm{~mm})$ with parallel dorsal and ventral margins. Four other species exhibit a strongly developed reticulation and, therefore, resemble $M$. martensi sp. nov. They can, however, be distinguished from the new species. $M$. quadrata is larger $(L 0.47 \mathrm{~mm})$ with parallel ventral and dorsal margins; M. amfibola (Barbeito-Gonzalez, 1971) is also larger ( $L 0.42 \mathrm{~mm}$ ) with a strongly developed and wide ventrolateral alar process; M. reticulata (Bonaduce et al., 1975) is slightly larger $(L 0.39 \mathrm{~mm})$ with wedge-shaped valves in lateral 
T. Namiotko et al.

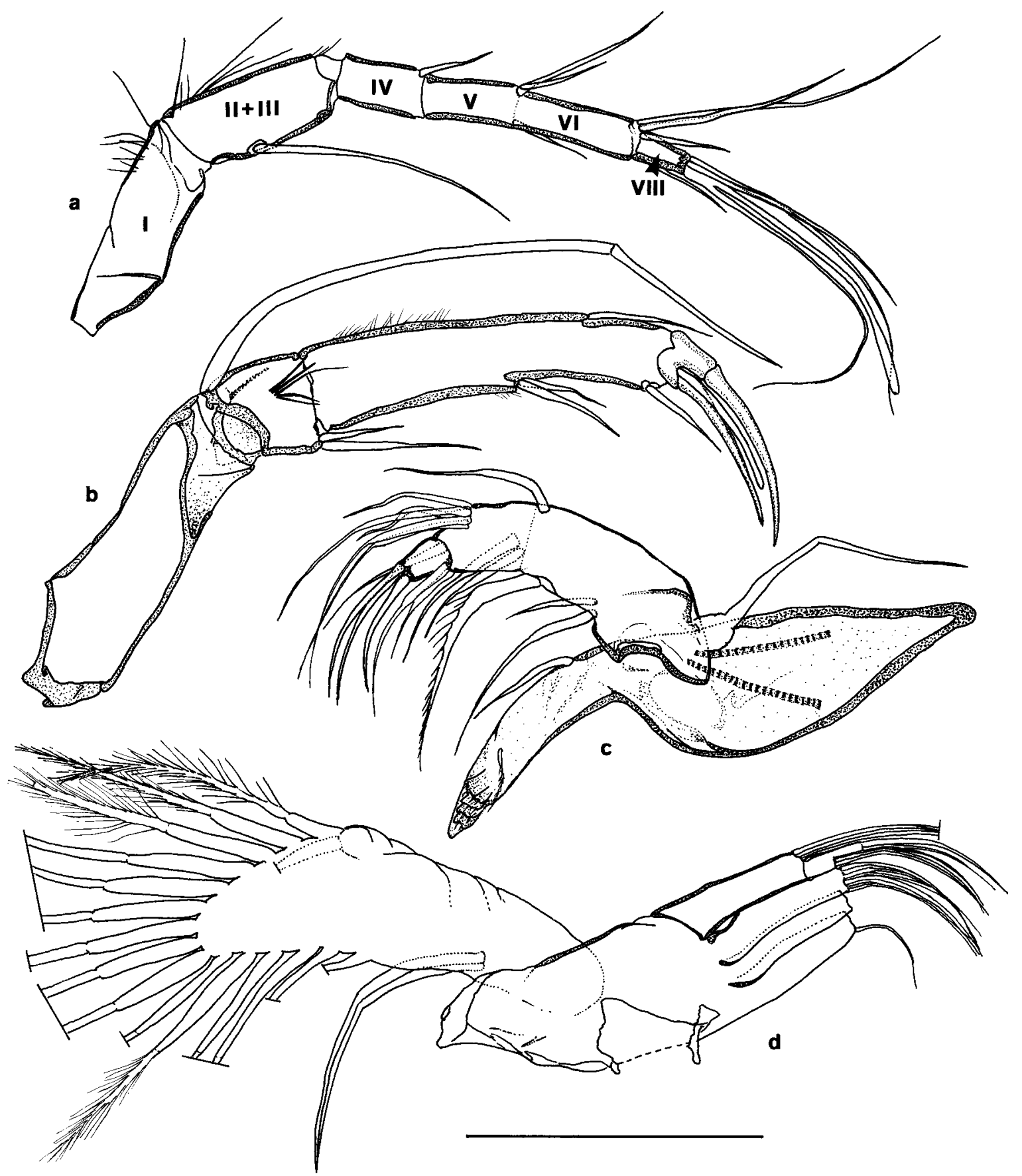

Fig. 3. Microceratina martensi sp. nov., Christmas Island, female holotype (C 28908): (a) antennule; (b) antenna; (c) mandible; (d) maxillula. Scale: $50 \mu \mathrm{m}$.

view because of the strongly tapering dorsal and ventral margins; and M. foveolata (Colalongo \& Pasini, 1980) is distinctly larger $(L \quad 0.51 \mathrm{~mm})$ with oblong valves and a convex dorsal margin.

Other species assigned to the genus Microceratina are not considered by the present authors as belonging to that genus. These are M. punctata Whatley \& Zhao, 1987, M. quadratamacroreticulata Yassini \& Jones, 1995, M. costata Herrig, 1991 and
Microceratina sp. 1 Whatley \& Downing, 1983. Mazzini \& Gliozzi (2000) noted that, because they have open pores, $M$. punctata, M. quadratamacroreticulata and Microceratina sp. 1 should not be included in the genus Microceratina. Further study is needed to establish the generic status of each of these species. Microceratina costata should be assigned to the genus Cytherura Sars (subfamily Cytherurinae G.W. Müller) owing to the outline and ornamentation of the valves. 


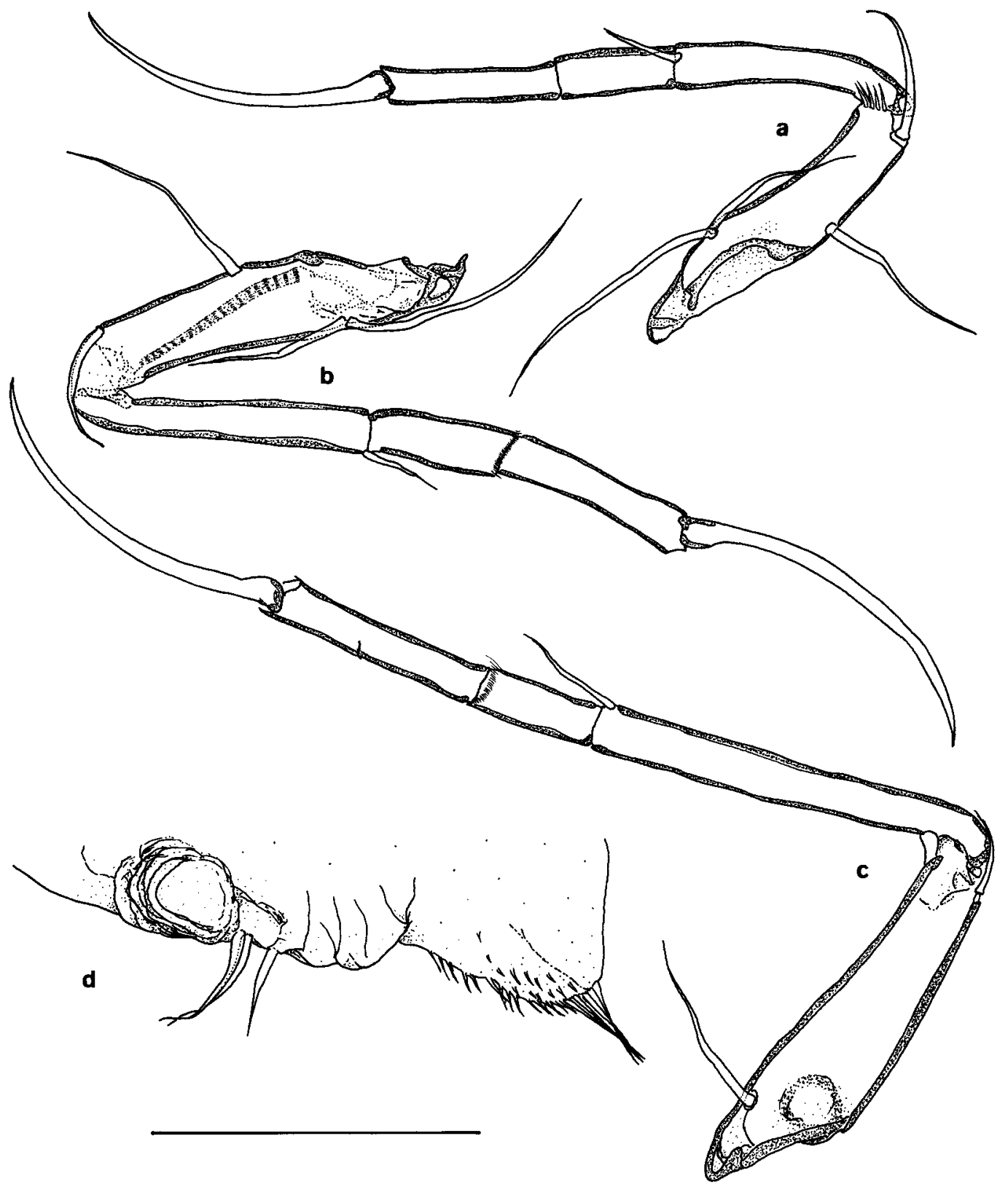

Fig. 4. Microceratina martensi sp. nov., Christmas Island, female holotype (C 28908): (a) first walking leg; (b) second walking leg; (c) third walking leg; (d) posterior end of the body and furca. Scale: $50 \mu \mathrm{m}$.

\section{PRESENT AND PAST GEOGRAPHICAL DISTRIBUTION OF MICROCERATINA SPECIES}

Figure 5 illustrates the known distribution of fossil and Recent Microceratina species.

The oldest known species of the genus, M. aequabilis Herrig, 1991, was found in Upper Maastrichtian erratic boulders on the Island of Rügen (Germany). The boulders probably originated in the middle to eastern Baltic Sea area where the source rocks were deposited during the Cretaceous in the relatively shallow seas of the Danish-Polish Furrow (Herrig, 1992). This area, situated at that time in the North European Province belonging to the North-temperate Realm, was close to the boundary of the Tethyan Realm and predominantly comprised warm to mid- temperate fauna (Kaufmann, 1973). There are no records of the genus from Palaeogene deposits. One of the Neogene representatives of the genus Microceratina (M. sp. 2 Whatley \& Downing) is known from Middle Miocene deposits in SE Australia (Whatley \& Downing, 1983). Two Recent species, $M$. quadrata and $M$. quadratamicroreticulata, occur today in coastal sediments off SE Australia (Yassini \& Jones, 1995) and southern New Zealand (Swanson, 1980). However, the most detailed data on the geographical and eco-stratigraphical distribution of Neogene to modern species of Microceratina are from the Mediterranean Basin. The oldest specimens from that area, from the Miocene of southern (Sicily) and northern (Piedmont) Italy, are M. poligonia (Ciampo, 1986), which is the other 


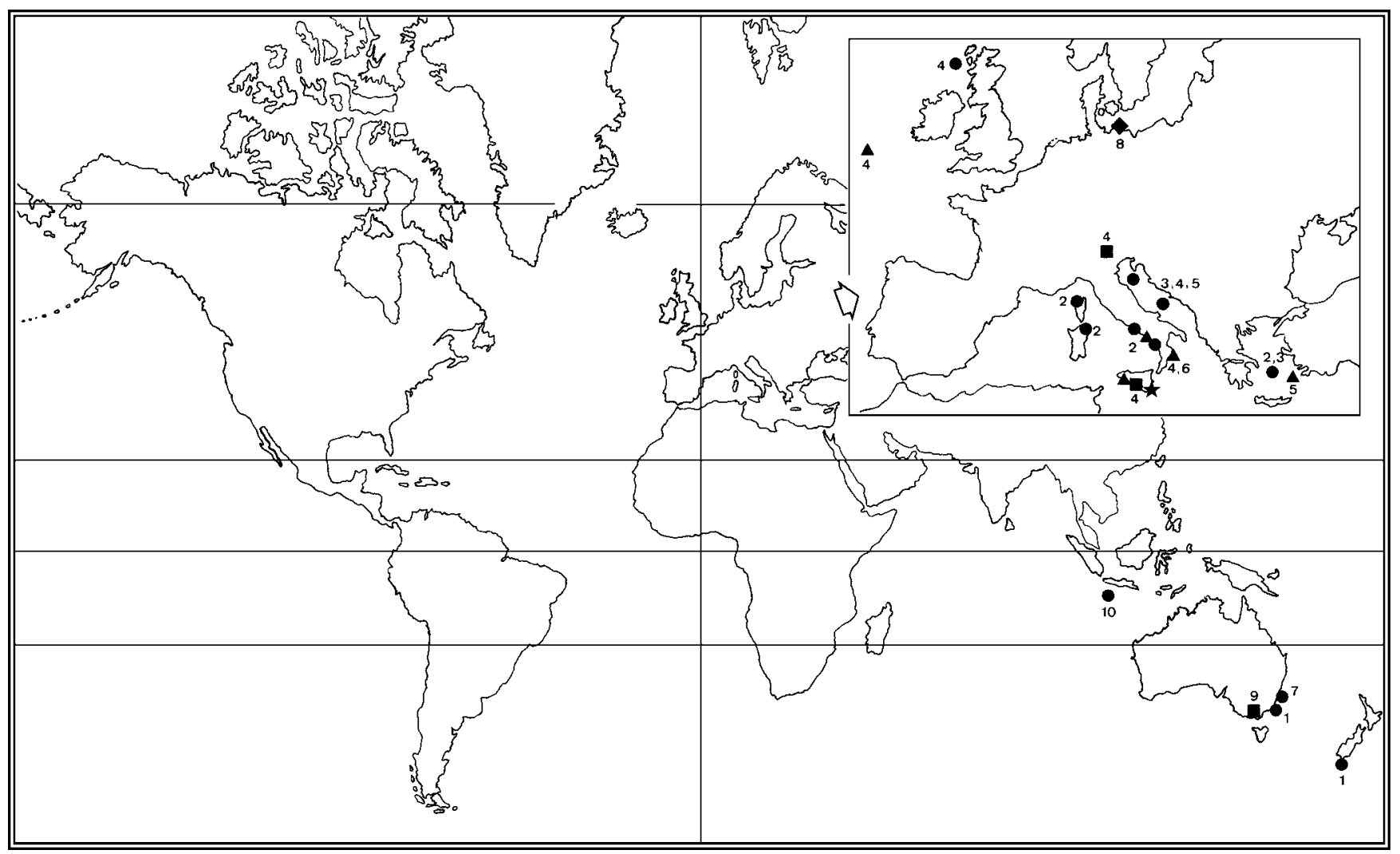

Fig. 5. Distribution of Microceratina-species. 1, M. quadrata Swanson, 1980; 2, M. pseudoamfibola (Barbeito-Gonzalez, 1971); 3, M. amfibola (Barbeito-Gonzalez, 1971); 4, M. poligonia (Colalongo \& Pasini, 1980); 5, M. reticulata (Bonaduce, Ciampo \& Masoli, 1975); 6, M. foveolata (Colalongo \& Pasini, 1980); 7, M. quadratamicroreticulata Yassini \& Jones, 1995; 8, M. aequabilis Herrig, 1991; 9, Microceratina sp. 2 Whatley \& Downing, 1983; 10, M. martensi sp. nov. (this paper). The distributions are based on the papers in which the species were described and others (Breman, 1975; Ciampo, 1976, 1986; Mostafawi, 1989; Peeters, 1994; Coles et al., 1996; Aiello et al., 2000; Mazzini \& Gliozzi, 2000; Aiello \& Barra, 2001; Arbulla et al., 2001). Circles, Recent; triangles, Quaternary; star, Pliocene; squares, Miocene; diamond, Late Cretaceous (see text for additional information).

Neogene representative of the genus. Microceratina poligonia has the widest known stratigraphical and geographical range of the genus and flourished for a very long time over a wide area. This species also occurred in Sicily throughout the Pliocene (Aiello \& Barra, 2001) and Pleistocene (Aiello et al., 2000). In the Mediterranean it is also known from the Early Pleistocene of Calabria, SW Italy (Colalongo \& Pasini, 1980) and from Recent sediments in the Adriatic Sea (as ?Eucytherura sp. in Breman, 1975). Finally, M. poligonia was reported from two sites in the NE Atlantic: late Pleistocene deposits SW of Ireland and (Sub-)Recent sediments west of Scotland (Coles et al., 1996). In addition to $M$. poligonia, three other species of the genus have been recorded from the Mediterranean Early Pleistocene: $M$. foveolata from Calabria, SW Italy (Colalongo \& Pasini, 1980), M. pseudoamfibola from Campania, SW Italy (Ciampo, 1976) and $M$. reticulata from Rhodos Island, Greece (Mostafawi, 1989). Microceratina still occurs in the Mediterranean. In addition to $M$. poligonia, three other species were sampled from Recent Mediterranean sediments. Microceratina amfibola was found at sites close to Naxos Island in the Aegean Sea (BarbeitoGonzalez, 1971) and from the Adriatic Sea (Bonaduce et al., 1975). Microceratina pseudoamfibola occurs in coastal sediments off Corsica (Peeters, 1994), NE Sardinia (Arbulla et al., 2001) and Naxos Island (Barbeito-Gonzalez, 1971). Of particular interest is the recent discovery by Mazzini \& Gliozzi (2000) of M. pseudoamfibola from a submarine cave in the Palinuro Bay in the Tyrrhenian Sea, SW Italy. Finally, M. reticulata was sampled in the Bay of Naples and in the Adriatic Sea (Bonaduce et al., 1975).

Prior to this paper, the geographical distribution of Microceratina species (Fig. 5) represented a disjunct distribution pattern, from Cretaceous to Recent, in warm to temperate zones on both sides of the tropics but not in tropical environments. The discovery of the new Microceratina species in the Indian Ocean is remarkable, therefore, being the first record of the genus in the tropics. There may be different explanations for this. First, other Microceratina species may occur in tropical seas and oceans but are yet unfound. It is known from both palaeontological studies and from studies on Recent ostracod shells, that very small species (smaller than $0.45 \mathrm{~mm}$ and termed 'micro-ostracods' by Herrig (1998)), are absent from or are poorly represented in the fossil record, being either overlooked, unrecognized or considered as juveniles. Recent publications, however, show that micro-ostracod fossil associations are occasionally preserved (Herrig, 1988, 1991, 1992, 1993, 1994, 1998; Pokorny, 1989; Danielopol et al., 1991; Danielopol \& Wouters, 1992; Herrig et al., 1997; Swain, 2000). For instance, Herrig (1998) described new micro-ostracods from Maastrichtian erratic boulders of the 
Baltic region. He observed remarkable morphological similarities between Late Cretaceous ostracods and Quaternary and Recent ostracods from the western Indo-Pacific Ocean in a number of genera, such as Puncia Hornibrook, Manawa Hornibrook, Pelecocythere Athersuch, Saida Hornibrook, Jankeijcythere McKenzie, Heinia Bold, Hanaicythere Yajima and Miracythere Hornibrook, as well as in Microceratina. $\mathrm{He}$ concluded that "the occurrence of morphologically similar species in the boreal Upper Cretaceous of the Danish-Polish Furrow and in Tertiary and Quaternary sediments of the Indo-Pacific realm confirms the hypothesis of a close biogeographic correspondence, in spite of the huge spatial and temporal distances" (Herrig, 1998, p. 2).

The Danish-Polish Furrow was part of the Tethyan Ocean during the Cretaceous and Microceratina can, therefore, be called a Tethyan genus with species dispersed along the northern margin of the Tethys. This is another example of the importance of the Tethyan corridor for ostracod distribution mainly during the Cretaceous and the Palaeogene, as emphasized by McKenzie (1986). Possibly, the Microceratina lineage developed a disjunct distribution later, but judging from the fossil evidence presented here, the distribution of the genus was already disjunct in the Miocene.

\section{ORIGIN AND EVOLUTION OF MICROCERATINA MARTENSI SP. NOV.}

This new ostracod species is a stygobiont and displays the typical troglomorphic traits known in other interstitial and/or cave-dwelling cytheroids, lacking ocular structures in possessing no eyes or ocular tubercles on the valves (cf. Hartmann, 1973; Danielopol \& Hartmann, 1985). In contrast, shallow water epibenthic species of the related genus Eucytherura G.W. Müller have strongly developed ocular structures in which the pigmented eyes project into well-developed ocular fossae on the carapace and which are visible from the outside as ocular tubercles (see the illustrations of G.W. Müller, 1894, table 20, figs 19 and 20 for E. gibbera and E. alata). Note, however, that bathyal and abyssal species of Eucytherura also lack ocular structures. In addition, the antennule and antenna of M. martensi sp. nov. display well-developed distal aesthetascs (Fig. 3a, b). In contrast, instead of aesthetascs only 'simple' setae occur in the other Eucytherurinae from open marine habitats for which appendages have been described. For example, species of the genera Eucytherura (e.g. E. gibbera G.W. Müller) and Xylocythere (e.g. X. pointillissima Maddocks \& Steineck).

The ecological distribution and the morphological details of the carapace of the Microceratina lineage suggest that this is a very flexible group evolutionarily. Species have adapted to a wide range of habitats such as sandy sediments at 20-50 m depth (M. quadrata from Port Pegasus Stewart Island: Swanson, 1980), sandy/silty sediments at depths no greater than 50-60 m (M. amfibola and M. pseudoamfibola in the Mediterranean: Barbeito-Gonzalez, 1971; Bonaduce et al., 1975), frigid conditions of the deep sea at depths of $650-750 \mathrm{~m}$ (M. poligonia in the North Atlantic from Recent and Quaternary facies: Coles et al., 1996) and anchialine caves in Southern Italy and Christmas Island. In Southern Italy M. pseudoamfibola is found in an anchialine cave habitat (Mazzini \& Gliozzi, 2000) comparable to that in which $M$. martensi sp. nov. was collected because in both systems the bottom is covered by rich organic matter, respectively plant detritus and plant roots.

The surface ornamentation and the degree of calcification of the carapaces of Microceratina show considerable variation. This ranges from the weakly ornate and thinly calcified valves of $M$. pseudoamfibola and $M$. martensi sp. nov., to the more strongly ornate valves of $M$. amfibola and Microceratina sp. 2 Whatley \& Downing. None of the known Microceratina species have ocular tubercules on the valves, possibly owing to the poor development of the inner ocular structures as seen in M. martensi sp. nov.

M. martensi sp. nov. has an extremely small carapace with elongate and barely ornate valves, similar to those typical of marine interstitial ostracods (Hartmann, 1973). This morphology suggests that $M$. martensi sp. nov. may also live outside the cave in the sublittoral interstitial sandy habitats of Christmas Island or even other oceanic islands. Tuberoloxoconcha tuberosa Hartmann occurs both in marine caves and in sublittoral interstitial habitats (Danielopol \& Bonaduce, 1990a) close to the locations where $M$. pseudoamfibola has been found (Mazzini \& Gliozzi, 2000). This suggests that the colonization of the anchialine caves in both southern Italy and on Christmas Island may have been by ostracods predisposed to inhabit aphotic subterranean habitats.

There is considerable evidence (Larwood \& Whatley, 1993; Larwood et al., 1996; Allmon \& Ross, 2001) that shallow benthic habitats of oceanic islands, including seamounts, were passively colonized from remote sources in the Tertiary to the Recent by a rich and diverse ostracod fauna. Even marine interstitial ostracods could have arrived by passive drift to volcanic islands like the Galapagos (Danielopol \& Bonaduce, 1990b). Therefore, the colonization of Christmas Island by a Microceratina species could have occurred from the Tertiary to the Recent, with cave colonization allowed by the karstification of the limestone during the Neogene. Most of the accompanying fauna sampled in the karstic system where $M$. martensi sp. nov. was found comprises epigean species, which could have reached the island by passive dispersal at any time, even recently. However, Procarididae appear to be restricted to anchialine caves where they are sympatric with one or more species of atyid shrimps. These co-occurrences of apparently ancient caridean families have been proffered as support for the contention that crevicular habitats have served as faunal refuges (Kensley \& Williams, 1986). The occurrence of procaridid, alpheid, hippolytid and atyid shrimps in the same anchialine system on Christmas Island is similar to that found on Bermuda (Hart \& Manning, 1981), renowned for its diversity of anchialine fauna (Iliffe, 1994). This, therefore, could be an argument for an old colonization of the subterranean habitats of this island by crustaceans, including also the Microceratina species described here. Because Recent Microceratina species exist in open marine habitats, the new species is not a relic (sensu Humphreys, 2000), which survived by using the Christmas Island karst system as a refugium, the argument used by Kensley \& Williams (1986) for the occurrence of decapod procaridids from other anchialine systems. Other seamount islands have endemic ostracod species belonging to other Eucytherurinae groups, as, for example Eucytherura on Ita Mai Tai and Horizon guyots in the Pacific 
Ocean (Larwood \& Whatley, 1993; Boomer \& Whatley, 1996; Larwood et al., 1996). Microceratina martensi sp. nov. appears to be endemic to Christmas Island.

\section{ACKNOWLEDGEMENTS}

TN was supported by a grant of the University of Gdañsk (no BW/1030-5-0054-2) as well as by the Scientific Exchange Programme of the Polish Academy of Sciences (PAN) and the Austrian Academy of Sciences (ÖAW). We thank I. Mazzini (Forschungsinstitut Senckenberg, Frankfurt/Main) for useful information pertaining to Microceratina pseudoamfibola in the Italian cave. For examining various taxa we thank R. Wilson (Melbourne Museum: Annelida), G. A. Boxshall (The Natural History Museum, London: Copepoda Harpacticoida and Cyclopoida), G. L. Pesce (University di l'Aquila, Italy: Copepoda Calanoida), J. Lowry (Australian Museum: Amphipoda), J. Short (Queensland Museum: Alpheidae, Procarididae, Hippolytidae), S. C. Choy (Water Resources Queensland: Atyidae, Palaemonidae). S. Eberhard's (Caveworks, Western Australia) skill in the water and observations greatly enhanced the work on Christmas Island. The field work on Christmas Island was funded (WFH) under contract to Parks Australia North (now Environment Australia).

\section{Manuscript received 30 January 2003 Manuscript accepted 23 May 2003}

\section{REFERENCES}

Adams, C.G. \& Belford, D.J. 1974. Foraminiferal biostratigraphy of the Oligocene-Miocene limestones of Christmas Island (Indian Ocean). Palaeontology, 17: 457-506.

Aiello, G. \& Barra, D. 2001. Pliocene ostracod assemblages at the M Pl 3-M Pl 4 boundary in the Cape Rossello borehole (Agrigento, Sicily). Bolletino della Societa Paleontologica Italiana, 40: 97-107.

Aiello, G., Barra, D. \& Bonaduce, G. 2000. Systematics and biostratigraphy of the Ostracoda of the Plio-Pleistocene Monte S. Nicola section (Gela, Sicily). Bolletino della Societa Paleontologica Italiana, 39: $83-112$.

Allmon, W.A. \& Ross, R.M. 2001. Nutrients and evolution in the marine realm. In: Allmon, W.A. \& Bottjier, D.J. (Eds), Evolutionary Paleoecology. The Ecological context of Macroevolutionary Change. Columbia University Press, New York, 105-148.

Arbulla, D., Pugliese, N. \& Russo, A. 2001. Ostracodi del Golfo Saline (Sardegna nord-orientale). Studi Trentini di Scienze Naturali, Acta Geologica, 77: 25-35.

Barbeito-Gonzalez, P.J. 1971. Die Ostracoden des Küstenbereichs von Naxos (Griechenland) und ihre Lebensbereiche. Mitteilungen aus dem Hamburgischen Zoologischen Museum und Institut, 67: $255-326$.

Barrett, F.J. 1985. Christmas Island water resources summary report. Internal Report, Christmas Island Phosphate Company, 20/2/1985, Christmas Island, 39 pp. (unpublished).

Barrie, J. 1967. The geology of Christmas Island. Bureau of Mineral Resources Record, Canberra, 1967/37, 45 pp. (unpublished).

Bonaduce, G., Ciampo, G. \& Masoli, M. 1975. Distribution of Ostracoda in the Adriatic Sea. Pubblicazione della Stazione Zoologica di Napoli, 40: 1-304.

Boomer, I.D. \& Whatley, R.C. 1996. Ostracod endemism on mid-Pacific guyots from ODP legs 143 and 144. In: Moguilevsky, A. \& Whatley, R. (Eds), Microfossils and Oceanic Environments. University of Wales Press, Aberystwyth, 403-412.

Breman, E. 1975. Distribution of ostracodes in the bottom sediments of the Adriatic Sea. PhD thesis. Vrije Universiteit Amsterdam, 165 pp.
Chappell, J. \& Thom, B.G. 1977. Sea levels and coasts. In: Allen, J., Golson, J. \& Jones, R. (Eds), Sunda and Sakul: Prehistoric studies in southeast Asia, Melanesia \& Australia. Academic Press, London, 275-291.

Ciampo, G. 1976. Ostracodi pleistocenici di Cala Bianca (Marina di Camerota, Salerno). Bolletino della Societa Paleontologica Italiana, 15: 3-23.

Ciampo, G. 1986. Ostracodi del limite Tortoniano/Messiniano in alcune sezione italiane. Bolletino della Societa Paleontologica Italiana, 24: $29-110$.

Colalongo, M.L. \& Pasini, G. 1980. La ostracofauna plio-pleistocenica della sezione Vrica in Calabria (con considerazioni sul limite Neogene/Quaternario). Bolletino della Societa Paleontologica Italiana, 19: 44-126.

Coles, G.P., Ainsworth, N.R., Whatley, R.C. \& Jones, R.W. 1996. Foraminifera and Ostracoda from Quaternary carbonate mounds associated with gas seepage in the Porcupine Basin, offshore Western Ireland. Revista Española de Micropaleontologia, 28: 113-151.

Danielopol, D.L. \& Bonaduce, G. 1990a. The colonisation of subsurface habitats by the Loxoconchidae Sars and the Psammocytheridae Klie. In: Whatley, R. \& Maybury, C. (Eds), Ostracoda and Global Events. Chapman \& Hall, London, 437-458.

Danielopol, D.L. \& Bonaduce, G. 1990b. The origin and distribution of the interstitial Ostracoda of the species group Xestoleberis arcturi Triebel (Crustacea). Courier Forschungsinstitut Senckenberg, 123: 69-86.

Danielopol, D.L. \& Hartmann, G. 1985. Ostracoda. In: Botosaneanu, L. (Ed.), Stygofauna Mundi. Brill, Leiden, 265-294.

Danielopol, D.L. \& Wouters, K. 1992. Evolutionary (palaeo) biology of marine interstitial ostracods. Geobios, 25: 207-211.

Danielopol, D.L., Piller, W.E. \& Huber, T. 1991. Pseudolimnocythere hainburgensis $\mathrm{n}$. sp. (Ostracoda, Loxoconchidae) aus dem Miozän (Badenium) des Wiener Beckens. Neues Jahrbuch für Geologie und Paläontologie Monatshefte, 8: 458-469.

Danielopol, D.L., Baltanás, A. \& Humphreys, W.F. 2000. Danielopolina kornickeri sp. n. (Ostracoda, Thaumatocypridoidea) from a western Australian anchialine cave: morphology and evolution. Zoologica Scripta, 29: 1-16.

Falkland, A. 1986. Christmas Island (Indian Ocean): water resources study in relation to proposed development at Waterfall. Department of Territories, Hydrology and Water Resources Unit. Report., 86/19: 123 pp.

Ford, D.C. \& Williams, P.W. 1989. Karst Geomorphology and Hydrology. Unwin Hyman, London, $601 \mathrm{pp}$.

Grimes, K.G. 2001. Karst features of Christmas Island (Indian Ocean). Helictite, 37: 41-58.

Hart, C.W. \& Manning, R.B. 1981. The cavernicolous caridean shrimps of Bermuda (Alpheidae, Hippolytidae, and Atyidae). Journal of Crustacean Biology, 1: 441-456.

Hartmann, G. 1973. Zum gegenwärtigen Stand der Erforschung der Ostracoden interstitieller Systeme. Annales de Spéléologie, 28: 417-426.

Hartmann, G. 1989. Ostracoda. In: Bronns, H.G. (Ed.), Klassen und Ordnungen des Tierreichs, 5, Sect 1. G. Fischer Verlag, Jena, 787-1067.

Herrig, E. 1988. Punciidae Ostrakoden aus der höheren Oberkreide der Mittleren Ostsee. Geschiebekunde Aktuell, 4: 33-37.

Herrig, E. 1991. Neue Ostrakoden aus verkieselten Kalksteinen der höhern Oberkreide (Ober-Maastricht) der Dänisch-Polnischen Furche/Ostsee. II. Geologisches Jahrbuch, A, 128: 99-115.

Herrig, E. 1992. Neue Ostrakoden aus verkieselten Kalksteine der höheren Oberkreide (Ober-Maastricht) der Dänisch-Polnischen Furche/Ostsee. I. Zeitschrift für Geologische Wissenschaften, 20: $27-49$.

Herrig, E. 1993. Gleiche Ostracodenarten aus Oberkreide und Tertiär/Quartär. Zitteliana, 20: 349-359.

Herrig, E. 1994. Polycopidae (Crustacea, Ostracoda) aus der borealen Oberkreide des mittleren und südlichen Ostseeraumes. Paläontologisches Zeitschrift, 68: 351-359.

Herrig, E. 1998. Mikroostrakoden (Cytheracea) des OberMaastrichtium aus dem Ostsee-Raum (Dänisch-Polnische Furche). Courier Forschungsinstitut Senckenberg, 204: 1-29. 
Herrig, E., Frenzel, P. \& Reich, M. 1997. Zur Mikrofauna einer Ober-Campan-Scholle von der Halbinsel Wittow (NW Rügen/Ostsee). Freiberger Forschungsheft, C468: 129-169.

Humphreys, W.F. 1999. Physico-chemical profile and energy fixation in Bundera Sinkhole, an anchialine remiped habitat in north-western Australia. Journal of the Royal Society of Western Australia, 82: 89-98.

Humphreys, W.F. 2000. Relict faunas and their derivation. In: Wilkens, H., Culver, D.C. \& Humphreys, W.F. (Eds), Ecosystems of the World. Subterranean Ecosystems, 30. Elsevier, Amsterdam, 417-433.

Humphreys, W.F. \& Eberhard, S.M. 1998. Assessment of the ecological values and management options for cave use on Christmas Island: Project 97/002. Unpublished report prepared for Parks Australia North, $134 \mathrm{pp}$.

Humphreys, W.F. \& Eberhard, S.M. 2001. Subterranean fauna of Christmas Island, Indian Ocean. Helictite, 37: 59-74.

Iliffe, T.M. 1994. Bermuda. In: Juberthie, C. \& Decu, V. (Eds), Encyclopaedia Biospeologica, 3. Laboratoire Souterrain du CNRS, Moulis, France, 417-424.

Iliffe, T.M. 2000. Anchialine cave ecology. In: Wilkens, H., Culver, D.C. \& Humphreys, W.F. (Eds), Ecosystems of the World. Subterranean Ecosystems, 30. Elsevier, Amsterdam, 59-76.

Kaufmann, E.G. 1973. Cretaceous Bivalvia. In: Hallam, A. (Ed.), Atlas of Biogeography. Elsevier Scientific Publishing Company, Amsterdam, 353-383.

Kempf, E.K. 1986. Index and bibliography of marine Ostracoda. 1, Index A. Sonderveröffentlichungen des Geologischen Instituts der Universität zu Köln, 50: 1-762.

Kensley, B. \& Williams, D. 1986. New shrimps (families Procarididae and Atyidae) from a submerged lava tube in Hawaii. Journal of Crustacean Biology, 6: 417-437.

Larwood, J. \& Whatley, R.C. 1993. Tertiary to Recent evolution of Ostracoda in isolation on seamounts. In: McKenzie, K.G. \& Jones, P.J. (Eds), Ostracoda and Life Sciences. Balkema, Rotterdam, 531-549.

Larwood, J., Whatley, R.C. \& Boomer, I.D. 1996. Ostracod evolution on seamounts: evidence from Horizon Guyot, Central Pacific Ocean (DSDP sites $44 \& 171$ ) and the Ninetyeast Ridge, East Indian Ocean (DSDP Site 214). In: Moguilevsky, A. \& Whatley, R.C. (Eds), Microfossils and Oceanic Environments. University of Wales Press, Aberystwyth, 385-401.

Maddocks, R.F. \& Steineck, P.L. 1987. Ostracoda from experimental wood-island habitats in the deep sea. Micropaleontology, 33: 318-355.

Mazzini, I. \& Gliozzi, E. 2000. Occurrence of fossil and Recent Microceratina Swanson 1980 (Ostracoda, Eucytherurinae) in the Mediterranean. Micropaleontology, 46: 143-152.

McKenzie, K.G. 1986. Ostracoda: new aspects of their biogeography. In: Gore, R.H. \& Heck, K.L. (Eds), Crustacean biogeography. Crustacean Issues, 4. Balkema, Rotterdam, 257-277.
Mostafawi, N. 1989. Limnische und marine Ostracoden aus dem Neogen der Insel Rhodos (Griechenland). Courier Forschungs-Institut Senckenberg, 113: 117-157.

Mylroie, J.E., Carew, J.L., Sealey, N.E. \& Mylroie, J.T. 1991. Cave development on New Providence Island and Long Island, Bahamas. Cave Science, 18: 139-151.

Müller, G.W. 1894. Die Ostracoden des Golfes von Neapel und der angrenzenden Meeresabschnitte. Fauna und Flora des Golfes von Neapel, 21: 1-404.

Peeters, M. 1994. Een systematische en actuopaleontologische studie van ostracoden in sedimenten van de Baai van Calvi (Corsica). Unpublished licentiate thesis. University of Leuven, $104 \mathrm{pp}$.

Pettifer, G.R. \& Polak, E.J. 1979. Christmas Island (Indian Ocean), geophysical survey for groundwater, 1976. Bureau of Mineral Resources, Geology and Geophysics Record 1979/33, Canberra, 47 pp. (unpublished).

Pokorny, V. 1989. Pussella and Saipanetta (Ostracoda, Crustacea) in the Lower Turonian of Bohemia, Czechoslovakia. Casopis pro Mineralogii a Geologii, 34: 225-237.

Polak, E.J. 1976. Christmas Island (Indian Ocean), geophysical survey for groundwater, 1973. Bureau of Mineral Resources, Geology and Geophysics Record 1976/100, Canberra, 37 pp. (unpublished).

Sket, B. 1996. The Ecology of anchialine caves. Trends in Ecology and Evolution, 11: 221-255.

Swain, F.M. 2000. Micro-Ostracoda from the Eocene of North Carolina: a suggested interstitial faunule. Revista Española de Micropaleontologia, 32: 411-420.

Swanson, K.M. 1980. Five new species of Ostracoda from Port Pegasus, Stewart Island. New Zealand Journal of Marine and Freshwater Research, 14: 205-211.

Vogel, P.N., Mylroie, J.E. \& Carew, J.L. 1990. Limestone petrology and cave morphology on San Salavador Island, Bahamas. Cave Science, 17: $19-30$.

Watts, C.H.S. \& Humphreys, W.F. 2000. Six new species of Nirridessus and Tjirtudessus (Dytiscidae; Coleoptera) from underground waters in Australia. Records of the South Australian Museum, 33: 127-144.

Whatley, R. \& Downing, S. 1983. Middle Miocene Ostracoda from Victoria, Australia. Revista Española de Micropaleontologia, 15: 347-406.

Whatley, R. \& Zhao, Q. 1987. Recent Ostracoda of the Malacca Straits. Part I. Revista Española de Micropaleontologia, 19: 327-366.

Woodroffe, C.D. 1988. Vertical movement of isolated oceanic islands at plate margins: evidence from emergent reefs in Tonga (Pacific Ocean), Cayman Islands (Caribbean Sea) and Christmas Island (Indian Ocean). Zeitschrift für Geomorphologie, Suppl., 69: 17-39.

Yassini, I. \& Jones, B.G. 1995. Foraminiferida and Ostracoda from estuarine and shelf environments on the southeastern coast of Australia. University of Wollongong Press, Wollongong, $485 \mathrm{pp}$. 